\title{
OPTIMIZATION OF CROPPING PATTERN AND STOCKING DENSITY FOR PRODUCTION OF BRACKISHWATER SHRIMP, PENAEUS MONODON
}

\author{
S. B. Saha*, Shamsun Nahar, Azhar Ali and S. L. Rahman \\ Bangladesh Fisheries Research Institute, Brackishwater Station, \\ Paikgacha, Khulna, Bangladesh
}

\begin{abstract}
An experiment was conducted to develop a culture system for producing brackishwater shrimp, Penaeus monodon, at a management strategy affordable for marginal to medium farmers. Shrimp was produced by two cropping patterns viz., short cycle (60 days) double crops and long cycle (120 days) single crop each at three stocking densities viz., 3, 5, $7 \mathrm{nos} . / \mathrm{m}^{2}$. The analysis of results revealed that production of shrimp of $913.57-1429.38 \mathrm{~kg} / \mathrm{ha}$ in long cycle single crop was higher than that of $804.42-1296.87 \mathrm{~kg} / \mathrm{ha}$ in aggregate of short cycle double crops at $3-5 \mathrm{nos} . / \mathrm{m}^{2}$ density, but at $7 \mathrm{nos} . / \mathrm{m}^{2}$ density, production of shrimp of $1899.39 \mathrm{~kg} / \mathrm{ha}$ was higher in short cycle double crops than that of $1857.31 \mathrm{~kg} / \mathrm{ha}$ in long cycle single crop. The differences in production between two cropping patterns at different densities were not significant. Gross margin was higher in high stocking ponds in both short and long cycle cropping pattern and it was 1.75 - 2.24 times higher in long cycle culture than that short cycle culture. However, considering higher benefit cost ratio and requirement of supply of oxygen for the production management, it can be surmised that production of shrimp in short cycle double crops at $5 \mathrm{nos} . / \mathrm{m}^{2}$ densities will be better affordable for marginal to medium farmers having limited resource.
\end{abstract}

Key words: Management strategy, shrimp, optimization, cropping pattern

\section{INTRODUCTION}

Shrimp, Penaeus monodon, culture in Bangladesh has grown by leaps and bounds and the industry has been generating Tk. 40 to 50 billion per year in terms of foreign exchange and lot of employment, and uplifting the living standard of people involved directly or indirectly with the industry, but this culture practice has suffered significant economic loss due to some major hurdles of disease outbreak in shrimp and the use of unscientific and inadequate management practices by many farmers. Due to lack of adequate resource, most of the marginal to medium farmers are very reluctant to adopt scientific interventions of culture management for increasing production. Due to these constraints, huge amount ( $>0.25$ million ha) of coastal impoundments can't be used effectively and remain underutilized in regard to rate of production. As a result, production of shrimp in Bangladesh is very low in

${ }^{*}$ Corresponding author. *Present address: Bangladesh Fisheries Research Institute Mymensingh2201, Bangladesh. E-mail: sbikashsaha@yahoo.com

(c) 2016 Zoological Society of Bangladesh DOI: 10.3329/bjz.v44i1.30174 
comparison to other shrimp producing countries. Application of semi-intensive culture technology would surely increase production. Saha et al. (1999) produced $1944-2274 \mathrm{~kg} /$ ha shrimp at $16 \mathrm{nos} / \mathrm{m}^{2}$ density. Saha et al. (2009a) also produced $1668-2467 \mathrm{~kg} / \mathrm{ha}$ shrimp at $9-15 \mathrm{nos} . / \mathrm{m}^{2}$ density in closed culture system. A few resourceful farmers are also producing more than 3.0 tons/ha/crop shrimp applying this technology at higher stocking density. But this technological intervention is not affordable by most of the farmers who are not that much resourceful.

It is obvious that density of stocking is an important factor affecting the survival and growth of crustaceans including shrimp as also demonstrated by Wasielesky et al. (2001), Li et al. (2007) and Saha et al. (2009a). On the other hand, the use of lower densities results in lower productivity affecting the feasibility of the waterbody. Therefore there is no alternate of increasing stocking density for achieving higher production, but higher density again needs higher technological interventions mainly supply of supplementary dissolved oxygen for the proper management of the pond ecosystem. For the marginal to medium farmers a production strategy, which will lead higher production but involves affordable technological intervention, is needed. As shrimp is one of the most important export earning commodities, it is important to consider a production increasing culture strategy that will be affordable by marginal to medium farmers. This will pave the way of increasing production and export earnings from this sector. In the above context with the objective of developing shrimp culture technology adoptable for marginal to medium farmers, an initiative was undertaken to develop a shrimp culture management strategy with reasonable higher production and less technological intervention. The idea of the initiative was to compare the production, management requirement and economics of shrimp, Penaeus monodon culture in short (60 days) cycle double crops with those of long (120 days) cycle single crop at different densities.

\section{MATERIAL AND METHODS}

Experimental design: The experiment was conducted in 12 on-station earthen ponds of 0.1 ha each of Bangladesh Fisheries Research Institute, Brackishwater Station, Paikgacha, Khulna, following the design as given in Table 1.

Pond preparation and culture management: The entire area of 12 ponds was encircled up to $1 \mathrm{~m}$ height with fine mesh nylon net as a measure of biosecurity. An in-pond nursery was prepared by encircling $40 \mathrm{~m}^{2}$ area in one corner of each pond with nylon net fastened in bamboo frame. The ponds were prepared by drying, liming soil with quick lime and dolomite (3:1 ratio) @ 250 $\mathrm{kg} / \mathrm{ha}$ and then filled with the tidal saline water up to a depth of one meter. 
Water was treated with chlorine@ 20 ppm to disinfect water and kill all animalcules. Fermented molasses were applied to the pond water to develop colour of water to prevent penetration of sunlight and then fertilized with urea and TSP@ 25 and $30 \mathrm{~kg} /$ ha, respectively for quick production of plankton. After production of sufficient plankton, required quantity of PCR tested good quality post larvae (PL 20) of shrimp, P. monodon were acclimatized to the pond water and stocked to the in-pond nursery on 09 April, 2014 following the design of the experiment (Table 1). In the nursery, the stocked PL were fed with commercial nursery feed $(40 \%$ crude protein). After 3rd week of nursery rearing, the juveniles were released to the whole pond by up-folding the nylon net of the nursery enclosure. In the grow-out ponds, the shrimps were also fed with commercial pellet feed (35\% crude protein) depending on the biomass of shrimp. Feed was offered four times a day. Growth of fishes was monitored at weekly interval and feed was adjusted accordingly. The apparent feed conversion ratio (FCR) was calculated based on total weight of shrimp and feed supplied.

Table 1. Design of the experiment

\begin{tabular}{lccc}
\hline$*$ Treatments & $\begin{array}{c}\text { Stocking } \\
\text { densities } \\
\left(\text { Nos. } / \mathrm{m}^{2}\right)\end{array}$ & $\begin{array}{c}\text { Culture period } \\
\text { (Days) }\end{array}$ & Crop(s) \\
\hline $\mathrm{T}_{1}$ & 3 & Short cycle (60) & Double \\
$\mathrm{T}_{2}$ & & Long cycle (120) & Single \\
$\mathrm{T}_{3}$ & 5 & Short cycle (60) & Double \\
$\mathrm{T}_{4}$ & & Long cycle (120) & Single \\
$\mathrm{T}_{5}$ & 7 & Short cycle (60) & Double \\
$\mathrm{T}_{6}$ & & Long cycle (120) & Single \\
\hline
\end{tabular}

*Two replications of each treatment.

The water of the ponds was treated with dolomite @ 15 ppm on monthly basis and fertilized with urea and TSP whenever necessary. Supplementary oxygen was provided to the ponds whenever necessary through agitating water by paddle wheel. When pond soil became blacken after 75 - 80 days of culture, zeolite@ 4 ppm was applied to the ponds of long cycle culture. But no application of zeolite was needed in short cycle culture. No additional water supply is needed in short cycle ponds. But in long cycle ponds, water had to add from adjacent tidal canal after 75 - 80 days of culture to replenish evaporated water. Feeding behaviour and well being of shrimp was checked twice daily by setting check tray. After 60 days of culture, shrimps of all short cycle ponds were harvested by complete dewatering and the ponds were prepared again for 2nd crop following the method as mentioned in 1st crop. But due to unavailability of quality seed, stocking of ponds was delayed by about 15 days. 
By this period, phytoplankton production was reduced and some unwanted aquatic weeds grew in the in-pond nurseries. However, post larvae (PL 20) of shrimp were stocked for 2 nd crop on 27 th June and harvested after 60 days of culture. Shrimps from the ponds of long cycle single crop were harvested after 120 days of culture.

Water quality monitoring: The water quality variables viz., temperature, depth, transparency, salinity, $\mathrm{pH}$ and total alkalinity were monitored at seven days interval and dissolved oxygen (DO) was monitored almost daily. Temperature was monitored by a mercury thermometer in the morning, depth of water by a depth gauge at noon, transparency by a Secchi disk at noon, $\mathrm{pH}$ by a digital $\mathrm{pH}$ meter in the morning, salinity by an optical refractometer (Atago, Japan) at noon, total alkalinity by titrametric method in the morning and DO was monitored by Knuden's titrametric method as mentioned in APHA (1992) just before sunrise.

Cost and margin analysis: Cost of production was calculated considering the variable cost only. This includes cost of nylon net, postlarvae, feed, bleaching, fertilizer, lime, molasses, zeolite, labour, supplementary oxygen supply, minor equipments, harvest and land lease value. As all costs of production in 2nd crop of short cycle was accomplished from return of 1 st crop, total production cost of short cycle double crops was calculated averaging production cost of both 1 st and 2nd crops. Return from sale of shrimp was considered as gross margin and benefit cost ratio (BCR) was calculated by dividing gross margin by cost of production.

\section{RESULTS AND DISCUSSION}

Water quality: The recorded average water quality variables are shown in Table 2. The water quality variables viz., temperature, depth, transparency, salinity, $\mathrm{pH}$ and total alkalinity were in congenial level for shrimp culture and there was no significant variation of these variables among different treatments. But remarkable variation in dissolved oxygen (DO) level among different treatments was observed. According to Zhang et al. (2006), DO should be considered as a key factor if success in shrimp culture is to be achieved. Therefore, DO levels $>4.0 \mathrm{mg} / 1$ are usually recommended for shrimp culture by McGraw et al. (2001) and Zhang et al. (2006). Lower level of DO may cause hypoxia and affect survival, growth, feed consumption and osmoregulation of shrimp as opined by Wannamaker and Rice (2000) and Mugnier and Soyez (2005). As shown from Fig. 1, late night DO in the present investigation was sufficient enough for shrimp growth and survival in ponds with 3 and 5 nos. $/ \mathrm{m}^{2}$ stocking densities of both crops of short cycle culture. But dissolved oxygen (DO) in ponds with 7 nos. $/ \mathrm{m}^{2}$ in both short cycle crops decreased to near 
about $3.0 \mathrm{mg} / 1$ in the late night after 56 days of culture (DOC). This level of DO is uncongenial for shrimp survival. Though no mortality of shrimp was observed, shrimp may become vulnerable to disease at this DO level. In long cycle culture (Fig. 2), DO level of ponds with $5 \mathrm{Nos} . / \mathrm{m}^{2}$ and $7 \mathrm{Nos} . / \mathrm{m}^{2}$ density decreased to uncongenial level in the late night after $91 \mathrm{DOC}$ and $56 \mathrm{DOC}$, respectively. In this situation, supplementary oxygen was supplied to the ponds for $1-2$ hrs/late night by agitating water with paddle wheel. Decrease in DO in the later part of culture period with $3 \mathrm{Nos} . / \mathrm{m}^{2}$ density in long cycle culture was not that much alarming for shrimp. In spite of that, supplementary oxygen was also supplied occasionally in some ponds in the late night to help in stabilizing the deposited organic material.

Table 2. Water quality variables of the experimental shrimp, Penaeus monodon, culture ponds

\begin{tabular}{|c|c|c|c|c|c|c|c|c|c|}
\hline \multirow[t]{2}{*}{ Variables } & \multicolumn{3}{|c|}{$\begin{array}{c}\text { 1st short cycle crop } \\
\text { (60 days) }\end{array}$} & \multicolumn{3}{|c|}{$\begin{array}{l}\text { 2nd short cycle crop } \\
\text { (60 days) }\end{array}$} & \multicolumn{3}{|c|}{$\begin{array}{l}\text { Long cycle crop } \\
\text { (120 days) }\end{array}$} \\
\hline & $\begin{array}{l}{ }^{*} \mathrm{Sd}- \\
3 / \mathrm{m}^{2}\end{array}$ & $\begin{array}{l}\text { Sd- } \\
5 / \mathrm{m}^{2}\end{array}$ & $\begin{array}{l}\mathrm{Sd}- \\
7 / \mathrm{m}^{2}\end{array}$ & $\begin{array}{c}\mathrm{Sd}- \\
3 / \mathrm{m}^{2}\end{array}$ & $\begin{array}{l}\mathrm{Sd}- \\
5 / \mathrm{m}^{2}\end{array}$ & $\begin{array}{c}\text { Sd- } \\
7 / \mathrm{m}^{2}\end{array}$ & $\begin{array}{c}\mathrm{Sd}- \\
3 / \mathrm{m}^{2}\end{array}$ & $\begin{array}{l}\mathrm{Sd}- \\
5 / \mathrm{m}^{2}\end{array}$ & $\begin{array}{l}\text { Sd- } \\
7 \mathrm{~m}^{2}\end{array}$ \\
\hline Temp. $\left({ }^{\circ} \mathrm{C}\right)$ & $\begin{array}{l}29.7- \\
34.0\end{array}$ & $\begin{array}{l}29.5- \\
34.2\end{array}$ & $\begin{array}{l}29.5- \\
35.0\end{array}$ & $\begin{array}{l}29.5- \\
31.0\end{array}$ & $\begin{array}{l}30.0- \\
31.5\end{array}$ & $29.5-31$ & $\begin{array}{l}29.5- \\
35.2\end{array}$ & $\begin{array}{l}30.2- \\
35.0\end{array}$ & $\begin{array}{l}30.0- \\
35.2\end{array}$ \\
\hline Depth & $108-117$ & 85-111 & 95.125 & $118-129$ & $104-127$ & 106-136 & $92-110$ & 93-115 & 114-129 \\
\hline $\begin{array}{l}\text { Transparency } \\
(\mathrm{cm})\end{array}$ & $30-40$ & $25-45$ & $25-35$ & $30-48$ & $27-40$ & $22-37$ & $32-47$ & $28-42$ & $25-45$ \\
\hline Salinity (ppt) & $10-17$ & $11-17$ & $11-17$ & $9-11$ & 9-11 & $9-11$ & $10-17$ & $11-17$ & $10-17$ \\
\hline $\mathrm{pH}$ & $8.2-8.9$ & $8.2-8.8$ & $8.1-8.8$ & $8.3-9.4$ & $8.3-9.4$ & $8.2-8.7$ & $7.0-9.2$ & $7.4-9.1$ & $7.5-9.0$ \\
\hline $\begin{array}{l}\text { Late night } \\
\text { DO (mg/1) }\end{array}$ & $4.0-6.3$ & $3.8-6.6$ & $2.3-6.0$ & $4.2-6.1$ & $4.3-6.2$ & $3.0-5.0$ & $3.4-6.1$ & $2.9-6.3$ & 2.5.6.5 \\
\hline $\begin{array}{l}\text { Alkalinity } \\
(\mathrm{mg} / \mathrm{l})\end{array}$ & $134-156$ & $\begin{array}{l}126- \\
163\end{array}$ & $\begin{array}{l}134- \\
160\end{array}$ & $88-108$ & $101-118$ & $120-140$ & $\begin{array}{l}106- \\
155\end{array}$ & $\begin{array}{l}112- \\
150\end{array}$ & $125-163$ \\
\hline
\end{tabular}

*Sd - Stocking density.

Production of shrimp: Final production performance of shrimp is extremely important in determining the profitability of any aquaculture system. The production performance of shrimp in both short and long cycle culture ponds are summarized in Table 2 . In the 1 st crop of short cycle culture, average body weight (ABW) of shrimp was $17.39,16.51$ and $15.87 \mathrm{~g}$ and production of shrimp was $406.92,747.80$ and $1007.92 \mathrm{~kg} / \mathrm{ha}$ at 3,5 and 7 Nos. $/ \mathrm{m}^{2}$ densities, respectively. Whereas in the 2nd crop of short cycle culture, ABW of shrimp was $20.42,16.03$ and $14.79 \mathrm{~g}$ and production of shrimp was $397.50,549.07$ and $891.52 \mathrm{~kg} / \mathrm{ha}$ at 3,5 and 7 nos. $/ \mathrm{m}^{2}$ densities, respectively. The lower production of shrimp in spite of higher average body weight in 2nd crop was due to less survival of shrimp than that of 1 st crop. As shown in Table 2. Production of aquatic weeds in the in-pond nursery might cause mortality of some delicate postlarvae in the nursery. In the long cycle culture, ABW of shrimp was 39.36, 

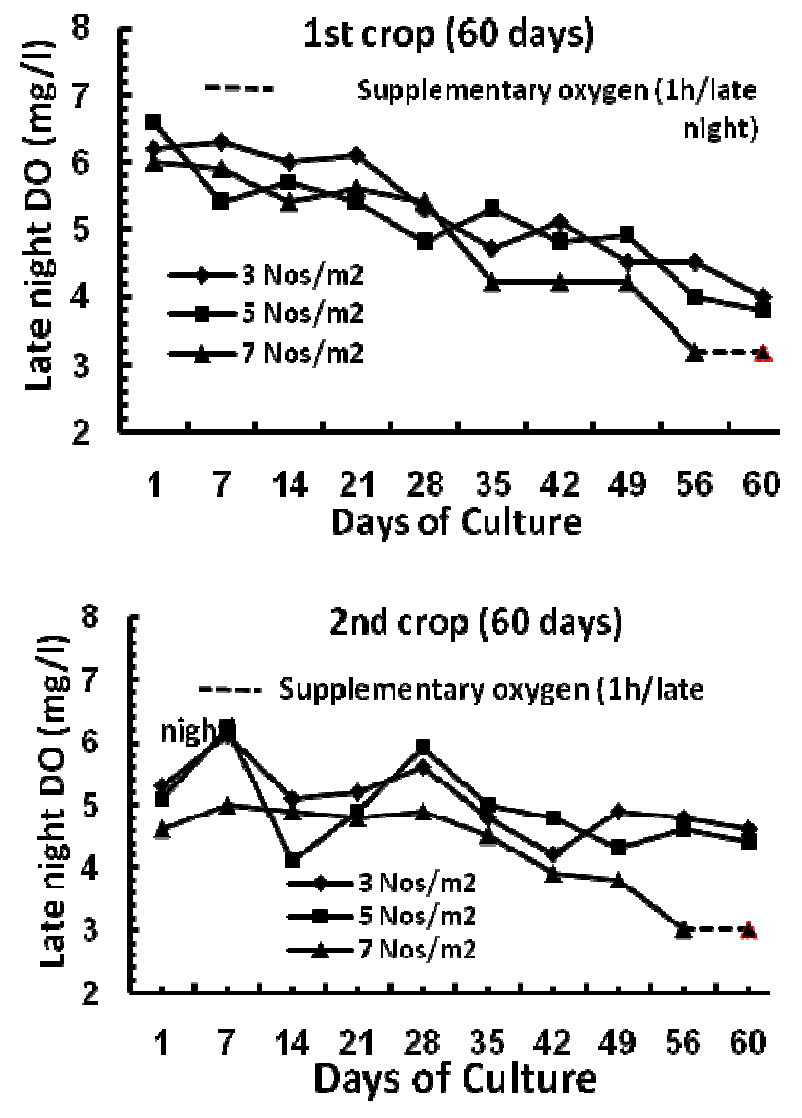

Fig. 1. Dissolved oxygen (DO) of the experimental ponds of short cycle culture of shrimp.

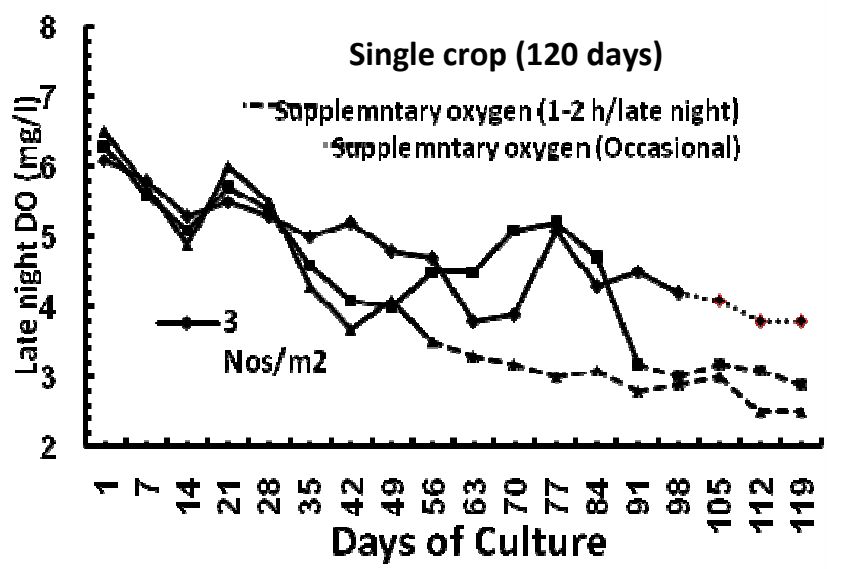

Fig. 2. Dissolved oxygen (DO) of the experimental ponds of long cycle culture of shrimp. 
32.51 and $30.51 \mathrm{~g}$ and average production of shrimp was 913.57, 1429.38 and $1857.31 \mathrm{~kg} /$ ha at 3,5 and $7 \mathrm{nos} . / \mathrm{m}^{2}$ densities, respectively indicating higher production of shrimp at high stocking densities as also observed in short cycle culture. Production of shrimp in long cycle culture was 13.57 and $10.22 \%$ higher than that of total production of both short cycle cultures at 3 and 5 nos. $/ \mathrm{m}^{2}$ stocking densities, respectively, but at 7 nos. $/ \mathrm{m}^{2}$, total production of both short cycle culture was $2.27 \%$ higher than that of long cycle culture. But the differences in production between short cycle (two cycles) and long cycle

Table 3. Production performance of shrimp, Penaeus monodon, in different culture systems

\begin{tabular}{|c|c|c|c|c|c|c|c|}
\hline Treatments & $\begin{array}{l}\text { Stocking } \\
\text { densities } \\
\left(\text { Nos. } / \mathrm{m}^{2}\right) \\
\end{array}$ & $\begin{array}{l}\text { Culture } \\
\text { period }\end{array}$ & Crop(s) & $\begin{array}{l}\text { ABW } \\
\text { (g) }\end{array}$ & $\begin{array}{c}\text { Survival } \\
(\%)\end{array}$ & $\begin{array}{l}\text { Production } \\
\text { (kg/ha) }\end{array}$ & FCR \\
\hline \multirow[t]{3}{*}{$\mathrm{T}_{1}$} & \multirow[t]{3}{*}{3} & \multirow{3}{*}{$\begin{array}{l}\text { Short cycle (60 } \\
\text { days) culture }\end{array}$} & First & 17.39 & 78.00 & 406.92 & 1.19 \\
\hline & & & Second & 20.42 & 65.07 & 397.50 & 1.16 \\
\hline & & & Total & & & 804.42 & \\
\hline $\mathrm{T}_{2}$ & & $\begin{array}{l}\text { Long cycle } \\
\text { (120 days) } \\
\text { culture }\end{array}$ & Single & 39.36 & 77.23 & 913.57 & 1.57 \\
\hline \multirow[t]{3}{*}{$\mathrm{T}_{3}$} & \multirow[t]{3}{*}{5} & \multirow{3}{*}{$\begin{array}{l}\text { Short cycle (60 } \\
\text { days) culture }\end{array}$} & First & 16.51 & 90.56 & 747.80 & 1.16 \\
\hline & & & Second & 16.03 & 68.81 & 549.07 & 1.20 \\
\hline & & & Total & & & 1296.87 & \\
\hline $\mathrm{T}_{4}$ & & $\begin{array}{l}\text { Long cycle } \\
\text { (120 days) } \\
\text { culture }\end{array}$ & Single & 32.79 & 86.92 & 1429.38 & 1.54 \\
\hline \multirow[t]{3}{*}{$\mathrm{T}_{5}$} & \multirow[t]{3}{*}{7} & \multirow{3}{*}{$\begin{array}{l}\text { Short cycle (60 } \\
\text { days) culture }\end{array}$} & First & 15.87 & 90.80 & 1007.86 & 1.13 \\
\hline & & & Second & 14.79 & 86.11 & 891.52 & 1.12 \\
\hline & & & Total & & & 1899.39 & \\
\hline $\mathrm{T}_{6}$ & & $\begin{array}{l}\text { Long cycle } \\
\text { (120 days) } \\
\text { culture }\end{array}$ & Single & 30.51 & 85.64 & 1857.31 & 1.63 \\
\hline
\end{tabular}

culture at all three stocking densities were insignificant. Though growth of shrimp was lower with the higher stocking densities, production of shrimp was significantly $(\mathrm{p}<0.01)$ higher at higher stocking densities in both short cycle and long cycle production systems. Production of shrimp in the present study was higher than that of Saha et al. (2008), who reported $660.03-831.45 \mathrm{~kg} / \mathrm{ha}$ shrimp using some commercial feed at $5 \mathrm{Nos} . / \mathrm{m}^{2}$ density. In another experiment, Saha et al. (2009b) found 694.30 - $945.46 \mathrm{~kg} / \mathrm{ha}$ shrimp at the same density. The higher present production at the same density might be due to use of quality feed and seed, and improved management. As shown in Table 3 , FCR value was higher in long cycle culture in comparison to that of short cycle culture at all stocking densities. This might be due to higher rate requirement of feed by larger size shrimp as also reported by Mohanty (2001), 
who observed that FCR of $P$. monodon increased in ponds as time progresses. The FCR in the present study is much less than that of $1.82-2.02$ and $1.22-$ 1.90 as reported by Saha et al. (2008) and Saha et al. (2009b), respectively. The application of quality feed and improved management system reduces the FCR in the present study. Boyd (2005) also reported that FCR varies with several factors including feed type and quality, production system and feeding technique.

Table 4. Cost of production and return from different shrimp, Penaeus monodon, culture systems

\begin{tabular}{|c|c|c|c|c|c|c|}
\hline Treatments & $\begin{array}{l}\text { Stocking } \\
\text { densities } \\
\left(\text { Nos. } / \mathrm{m}^{2}\right)\end{array}$ & $\begin{array}{l}\text { Culture } \\
\text { period }\end{array}$ & Crop(s) & $\begin{array}{l}{ }^{*} \text { Cost of } \\
\text { production } \\
(\mathrm{BDT} / \mathrm{ha})\end{array}$ & $\begin{array}{l}\text { Gross return } \\
\text { (BDT/ha) }\end{array}$ & BCR \\
\hline \multirow[t]{3}{*}{$\mathrm{T}_{1}$} & \multirow[t]{3}{*}{3} & \multirow{3}{*}{$\begin{array}{l}\text { Short cycle ( } 60 \text { days } \\
\text { each) culture }\end{array}$} & First & 116356 & 182812 & 1.57 \\
\hline & & & Second & 115240 & 226575 & 1.96 \\
\hline & & & Total & 115798 & 409387 & 3.54 \\
\hline $\mathrm{T}_{2}$ & & $\begin{array}{l}\text { Long cycle ( } 120 \\
\text { days) culture }\end{array}$ & Single & 333945 & 917745 & 2.70 \\
\hline \multirow[t]{3}{*}{$\mathrm{T}_{3}$} & \multirow[t]{3}{*}{5} & \multirow{3}{*}{$\begin{array}{l}\text { Short cycle ( } 60 \text { days } \\
\text { each) culture }\end{array}$} & First & 176590 & 336485 & 1.91 \\
\hline & & & Second & 158730 & 236100 & 1.49 \\
\hline & & & Total & 167660 & 572585 & 3.42 \\
\hline $\mathrm{T}_{4}$ & & $\begin{array}{l}\text { Long cycle (120 } \\
\text { days) culture }\end{array}$ & Single & 446235 & 1250153 & 2.80 \\
\hline \multirow[t]{3}{*}{$\mathrm{T}_{5}$} & \multirow[t]{3}{*}{7} & \multirow{3}{*}{$\begin{array}{l}\text { Short cycle ( } 60 \text { days } \\
\text { each) culture }\end{array}$} & First & 226496 & 453530 & 2.00 \\
\hline & & & Second & 216710 & 383353 & 1.77 \\
\hline & & & Total & 221603 & 836883 & 3.78 \\
\hline $\mathrm{T}_{6}$ & & $\begin{array}{l}\text { Long cycle (120 } \\
\text { days) culture }\end{array}$ & Single & 565955 & 1461056 & 2.60 \\
\hline
\end{tabular}

*Includes cost of nylon net, postlarvae, feed, bleaching, fertilizer, lime, molasses, zeolite, labour, supplementary oxygen supply, minor equipments, harvest and land lease value.

Cost and return of production: Cost and return from production of different culture systems are shown in Table 4. Total cost of production in long cycle culture was Tk. 3,33945/ha, Tk. 4,46,235/ha and Tk. 565955/ha at 3, 5 and 7 nos. $/ \mathrm{m}^{2}$ densities, respectively. This cost of production was $2.55-2.88$ times higher than that of short cycle culture. Cost of production in both short and long culture cycles was higher in ponds with higher stocking densities because of involvement of higher inputs (seed and feed) and excess cost of supplementary oxygen supply. Gross margin of long cycle culture was Tk. 9,17,745/ha, Tk. $12,50,153 /$ ha and Tk. 14,61,056/ha at the above three densities, respectively and these were $1.74-2.44$ times higher than those of short cycle culture. Gross margin was higher in ponds with higher stocking density in both short and long cycle culture systems. Benefit cost ratio (BCR) of short cycle culture was 3.54, 
3.42 and 3.78 at 3,5 and 7 nos $/ \mathrm{m}^{2}$ densities, respectively, which was 1.22 1.48 times higher than that of long cycle culture. This indicates higher rate of return in short cycle culture system.

\section{CONCLUSION}

The intensification of culture practice increases not only the total revenue but also the production cost and associated risks (Krummenauer et al. 2010). Production cost level may also help farmers to make decision and adjustment in the production system as also reported by Ahmed et al. (2008). Form the present study, it is also obvious that both production and income is higher in intensified culture system. But it is not possible to follow the intensified culture system with higher stocking density involving high technological intervention by most of the farmers due to lack of resource and fund. It is revealed that long cycle culture practice even at $3 \mathrm{Nos} / \mathrm{m}^{2}$ densities needs supply of additional oxygen and more than double investment is needed than that of short cycle culture. Besides, generally there is more risk of invasion of viral disease, if culture is lingered, though no disease occurrence was observed in this study. Even short cycle culture at 7 nos. $/ \mathrm{m}^{2}$ density would not be a feasible culture practice because this practice also needs additional oxygen supply, which is not also affordable by most of the farmers. Besides in long cycle culture, additional water supply is needed to replenish the evaporated water.

Considering all these facts and need in increase of production of shrimp in the country, production strategy of shrimp in short cycle double crop at 5 nos. $/ \mathrm{m}^{2}$ density which needs low technological intervention and investment can be followed by the marginal to medium farmers. The production of shrimp from culture in Bangladesh in 2013 - 14 was 1, 28, 313 MT from 2, 75, 274 ha shrimp farms (DoF 2015) indicating $466.13 \mathrm{~kg} / \mathrm{ha}$ rate of production. Production of shrimp in short cycle double crops at $5 \mathrm{nos} . / \mathrm{m}^{2}$ density was $1296.87 \mathrm{~kg} /$ ha which is 2.78 times higher than that of existing national average shrimp production. It is possible to increase the existing production into about double, if shrimp can be produced in half of the existing shrimp culture farms using the aforesaid strategy of short cycle double crops at 5 nos. $/ \mathrm{m}^{2}$ density. Of course, timely supply of good quality postlarvae of shrimp and feed should be ensured to achieve expected production.

\section{LITERATURE CITED}

AHMED, N. AHAMED, F. and BRAKEL, M.V. 2008. An economic analysis of freshwater prawn, Macrobrachium rosenbergii faming in Mymensingh, Bangladesh. J. World Aquacult. Soc. 39: 37-50.

APHA (American Public Health Association). 1992. Standard methods for the examination of water and waste water. 18th ed., APHA, Washington, D.C. 
BOYD, C.E. 2005. Feed efficiency indicators for responsible aquaculture. Global Aquacult. Advocate 8(6): 73-74.

DoF (Department of Fisheries). 2015. National Fish Week 2015 Compendium (in Bengali). DoF, Ministry of Fisheries and Livestock, Bangladesh. 148 pp.

KRUMMENAUER. D, CAVALI, R.O., BALLESTER, E.L.C. and WASIELESKY JR., W. 2010. Feasibility of Pacific white shrimp Litopeanaeus vannamei culture in southern Brazil: Effects of stocking density and a single or a double crop management strategy in earthen ponds. Aquacult. Res. 41: 24-248.

LI. X., DONG, S., LEI, Y. and LI, Y. 2007. The effect of stocking density of Chinese mitten crab Eriocheir sinensis on rice and crab seed yields in rice crab-crab culture systems. Aquaculture 273: 487-493.

MOHANTY, R.K. 2001. Feeding management and waste production in semi-intensive farming of Penaeus monodon (Fab.) at different stocking densities. Aquacult. International 9(4): 345-355.

MCGRAW, W., TEICHERT-CODDINGTON, D.R., ROUSE, D.B. and BOYD, C.E. 2001. Higher minimum dissolved oxygen concentrations increase penaeid shrimp yields in earthen ponds. Aquaculture 199: 311-321.

MUGNIER, C. and SOYEZ, C. 2005. Response of the blue shrimp Litopenaeus stylirostris to temperature decrease and hopoxia in relation to molt stage. Aquaculture 244: 315-322.

SAHA, S.B., BEGUM, N. and ALAM, M.J. 2009a. Optimization of stocking density of shrimp (Penaeus monodon) for semi-intensive culture in modified closed system. Bangladesh J. Agri. 34(1): 4350 .

SAHA, S.B., BEGUM, N. and ALAM, M.J. 2009b. Production and economic performance of different commercial feeds in brackishwater shrimp, Penaeus monodon farming. J. Asiatic Soc. Bangladesh Sci. 35(2): 153-161.

SAHA, S. B., BHATTACHARYYA, S.B. and CHOUDHURY, A. 1999. Production potential of Penaeus monodon (Fab.) in low saline environment. J. Aqua. Trop. 14(4): 319-325.

SAHA, S. B., ISLAM, M.S. and ALAM, M.J. 2008. Impact nitrogenous fertilizer on the growth and production of tiger shrimp, Penaeus monodon (Fabricius, 1798). Bangladesh J. Zool. 36(1): 49-58.

WANNAMAKER, C. M. and RICE J.A. 2000. Effects of hypoxia on movements and behavior of selected estuarine organisms from the southeastern United States. J. Expt. Mar. Biol. Ecol. 249: 145-163.

WASIELESKY, W. J., POERSH, L. H., JENSEN, L. and BIANCHINI, A. 2001. Effect of stocking density on pen reared pink shrimp Farfantepenaeus paulensis (Pérez-Farfante, 1967) (Decapoda, Penaeidae). Nauplis 9: 163-167.

ZHANG, P., ZANG, X. and HUANG G. 2006. The effects of body weight, temperature, salinity, pH, light intensity and feeding condition on lethal DO levels of white leg shrimp, Litpenaeus vannamei (Boone, 1931). Aquaculture 256: 579-587.

(Manuscript received on 21 December, 2015; revised on 18 June, 2016) 